\title{
COMPARATIVE ANALYSIS OF DIMENSIONS OF TEACHER COMMITMENT
}

\author{
V. Parthiban*
}

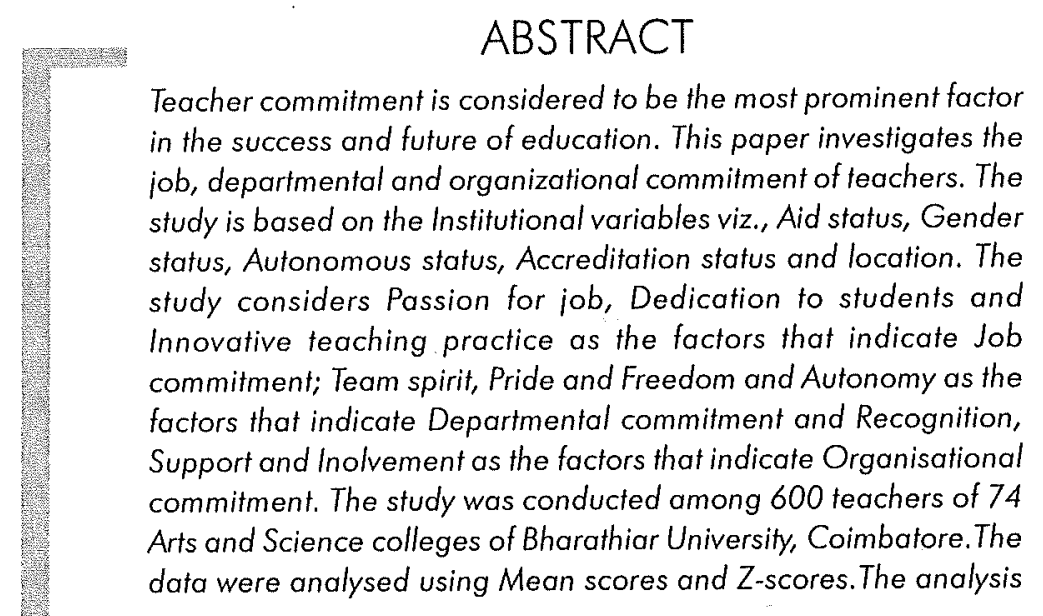

* Lecturer (SG) in Management, Gobi Arts \& Science College, Gobichettipalayam-638 453, Erode Disfrict, Tamilnadu. 
indicates that the teachers are highly commited to their job. Their departmental commitment comes much closer to job commitment. However, their organizational commitment is somehow less than their job and departmental commitment.

\section{Introduction}

Teacher commitment refers not only to practice but also to the core set of values or beliefs about education that each teacher held. There are many unanswered questions about the factors that influence teachers' commitment. Most of the research on organizational commitment has been done by industrial-organizational and occupational psychologists (Mueller, Wallace \& Price, 1992). Given the importance of knowledge capital, understanding why teachers become committed and stay committed to the organization seems necessary. Very little research on organizational commitment has been conducted within educational settings

Teachers' organizational commitment cannot be viewed in the same way as worker's / manager's organizational commitment. Teacher's job is a peculiar one. Educational institutions function in a semi formal way. A teacher works with learners who are vibrating with youthful energy and having their own ambitions and aspirations. As such his commitment to his job is of a peculiar nature. It reflects an integrated complex of the spirit of a preacher, the zeal of a machinery, the concern of the parent, an agency of socialization and dedication of a reformer.

\section{Statement of the problem}

The few past studies regarding teacher commitment focused mainly on two dimensions -viz., Job and Organization and the third dimension viz., Department did not find much mention in these studies. The formal group, in this case department, to which the teachers belong also have a considerable influence on their commitment. Hence, it is desirable to study the group or departmental commitment along with job and organization commitment. The pertinent constituents of each dimension of teacher commitment are identified by the researcher as follows:

Job Commitment: Passion for job, Dedication to students and Innovative teaching practices 
Departmental Commitment: Team Spirit, Pride and Freedom and Autonomy

Organisational Commitment: Recognition, Support and Involvement

\section{Population and sampling}

The seventy four Arts and Science Colleges of Bharathiar University where chosen as the study area. 4874 teachers of these colleges constitute the population of the study and the data were collected from 600 teachers using non probability, Quota-cum-convenience sampling.

\section{Profile of the respondents}

Of the 600 respondents selected for the study, a considerable number of them (40.5\%) belong to low age category followed by the respondents of Medium age category $(37.0 \%)$. The high age category respondents are fewer in number when compared to low and medium age category respondents. Of the total respondents, male (49.3\%) and female $(50.7 \%)$ respondents are almost equal in number. As far as the Educational Qualification is concerned more than three fourth of the respondents are M.Phil., qualified (79.8\%) and $12.2 \%$ of them are Ph.D. qualified. Only a small percentage of teachers (8\%) have just PG qualification. With regard to designation of teachers, a majority of them $(56.0 \%)$ are in the Lecturer Category, whereas Senior Scale and Selection Grade Lecturers are more or less equal in number. (19.7\% and $17.2 \%$ respectively). Only a small number of teachers $7.2 \%$ are in the Reader Category. As far as the faculty of the teachers is concerned, a majority of them (59.8\%) belong to Arts faculty and $40.2 \%$ of them belong to Science faculty.

Around two third of the respondents (65.7\%) belong to Self-financing Colleges and around one third of them (34.2\%) belong to Government and Government Aided Colleges. As far as the Gender Status of the colleges is concerned, around three fourth(76.0\%) of the respondents belong to Coeducational colleges, a considerable number of them (21.7\%) belong to Women's colleges and a small number of respondents $(0.5 \%)$ belong to Men's colleges. With regard to the classification of respondents based on Autonomous status of colleges around four fifth of the respondents (79.3\%) belong to Non-autonomous colleges whereas around one fifth of the respondents (20.7\%) belong to Autonomous colleges.Classification of respondents based on Accreditation status of colleges reveals that majority 
of the respondents $(59.3 \%)$ belong to Non-accredited colleges and the remaining respondents ( $40.7 \%$ ) belong to accredited colleges. As far as the location of institution is concerned, a majority of the respondents (52.\%) are employed in the Institutions located in the Rural area. It is notable that $27.3 \%$ of the respondents employed in the Institutions located in Semiurban area and around one fifth of the respondents (20.2\%) are employed in the Institutions located in Urban area.

\section{Hypothesis}

Job Commitment, Departmental Commitment and Organizational Commitment are the core dimensions of teacher commitment. The intriguing question is whether these dimensions are at equal level or at varied levels. A comparative analysis on dimensions of commitment of teachers is done with the following hypothesis in mind.

Ho:There is no significant difference between various dimensions of commitment of teachers viz., Job, Departmental and Organization based on the institutional variables viz., Aid status, Gender status, Autonomous status, Accreditation status and Location.

\section{Analysis}

The data collected from the primary source were analyzed using the statistical tools viz., Mean scores and Z - Test.

\section{Dimensions of Commitment and Aid Status}

The mean scores of opinion of the respondents belonging to Govt. and Aided colleges and self-financing colleges with regard to different dimensions of commitment are given in the following table:

Table 1: Mean scores of Job, Departmental, Organizational and Overall commitments

\begin{tabular}{|l|c|c|c|c|}
\hline \multicolumn{1}{|c|}{ Aid Status } & \multicolumn{4}{|c|}{ Mean Scores of Dimensions of Commitment } \\
\cline { 2 - 5 } & Job & Departmental & Organizational & Overall \\
\hline Govt. and Aided $(N=206)$ & 4.2102 & 4.1976 & 3.8728 & 4.0812 \\
Self Financing $(N=394)$ & 4.2667 & 4.2013 & 3.8460 & 4.0966 \\
Total $(N=600)$ & 4.2473 & 4.2000 & 3.8852 & 4.0913 \\
\hline
\end{tabular}


It is seen in the mean score table, that the teachers belong to both Government and Aided Colleges and Self-financing Colleges have highest mean scores in respect of Job Commitment followed by Departmental Commitment and Organizational Commitment.

The significance of difference in mean scores between dimensions of commitment is illustrated in the following table:

Table 2: Significance of difference in mean scores between dimensions of commitment based on Aid status (z-test)

\begin{tabular}{|l|r|r|r|r|r|r|r|}
\hline \multirow{2}{*}{ Aid Status } & \multirow{2}{*}{$\mathrm{N}$} & \multicolumn{5}{|c|}{ Z Values } \\
\cline { 3 - 7 } & & $\mathrm{J} \& \mathrm{D}$ & $\mathrm{J} \& \mathrm{O}$ & $\mathrm{J} \& \mathrm{~T}$ & $\mathrm{D} \& \mathrm{O}$ & $\mathrm{D} \& \mathrm{~T}$ & $\mathrm{O} \& \mathrm{~T}$ \\
\hline Govt. and Aided & 206 & 0.561 & $11.754^{\star \star}$ & $8.783^{\star \star}$ & $12.254^{\star \star}$ & $8.683^{\star \star}$ & $-12.154^{\star \star}$ \\
Self Financing & 394 & $3.588^{\star \star}$ & $18.190^{\star \star}$ & $15.020^{\star \star}$ & $14.848^{\star \star}$ & $8.646^{\star \star}$ & $-17.273^{\star \star}$ \\
\hline
\end{tabular}

J-Job Commitment; D-Departmental Commitment; O-Organizational Commitment; T-Total Commitment

** Significant at $1 \%$ level * Significance at $5 \%$ level

The $Z$ value with regard to Job and Departmental Commitment of the respondents belonging to Government and Aided Colleges is less than the table value. Hence, the hypothesis accepted in this case only. In all other cases, it is rejected.

It is evident from the table that in the case of Lecturers belonging to Government and Aided Institutions there is no significant difference between mean scores with regard to Job Commitment and Departmental Commitment. This indicates that job commitment and departmental commitment of teachers of Govt. and Aided colleges are at the same level and these commitments are higher than their organizational commitment. The teachers of self-finance colleges have higher job commitment than departmental commitment and their departmental commitment is higher than the organizational commitment.

\section{Dimensions of Commitment and Gender Status}

The mean scores of opinion of the respondents belonging to Men, Women and Co-educational institutions with regard to different dimensions of commitment are given in the following table: 
Table 3: Mean Scores of Job, Departmental, Organizational and Overall Commitments

\begin{tabular}{|l|c|c|c|c|}
\hline \multirow{2}{*}{$\begin{array}{c}\text { Gender Status of } \\
\text { institutions }\end{array}$} & \multicolumn{4}{|c|}{ Mean Scores of Dimensions of Commitment } \\
\cline { 2 - 5 } & Job & Departmental & Organizational & Overall \\
\hline Men $(\mathrm{N}=14)$ & 4.1452 & 4.1607 & 3.7022 & 3.9912 \\
Women $(\mathrm{N}=130)$ & 4.3049 & 4.2508 & 3.9499 & 4.1598 \\
Co-education $(\mathrm{N}=456)$ & 4.2340 & 4.1867 & 3.8328 & 4.0748 \\
\hline Total $(\mathrm{N}=600)$ & 4.2473 & 4.2000 & 3.8852 & 4.0913 \\
\hline
\end{tabular}

It is observed from the mean score table, that in case of teachers working in mens' colleges, the mean scores of Departmental Commitment is highest followed by Job Commitment and Organizational Commitment and in the Womens' and Co-educational Colleges the mean score of Job Commitment is the highest followed by Departmental and Organizational Commitment.

The significance of difference in mean scores between dimensions of commitment is illustrated in the following table :

Table 4: Significance of difference in mean scores between dimensions of commitment based on Gender status (z-test)

\begin{tabular}{|l|r|r|r|r|r|r|r|}
\hline \multirow{2}{*}{ Gender Status } & N & \multicolumn{5}{|c|}{ Z Values } \\
\cline { 3 - 7 } & & $\mathrm{J} \& \mathrm{D}$ & $\mathrm{J} \& \mathrm{O}$ & $\mathrm{J} \& \mathrm{~T}$ & $\mathrm{D} \& \mathrm{O}$ & $\mathrm{D} \& \mathrm{~T}$ & $\mathrm{O} \& \mathrm{~T}$ \\
\hline Men & 14 & -0.156 & $4.690^{\star \star}$ & $3.151^{\star \star}$ & $3.461^{\star \star}$ & $2.350^{\star *}$ & $-4.230^{\star \star}$ \\
Women & 130 & 1.673 & $8.724^{\star \star}$ & $6.817^{\star \star}$ & $8.203^{\star \star}$ & $4.791^{\star \star}$ & $-8.915^{\star \star}$ \\
Co-education & 456 & $2.934^{\star \star}$ & $19.376^{\star \star}$ & $15.765^{\star *}$ & $16.783^{\star \star}$ & $10.577^{\star \star}$ & $-18.641^{\star \star}$ \\
\hline
\end{tabular}

J-Job Commitment; D-Departmental Commitment; O-Organizational Commitment; T-Total Commitment

** Significant at $1 \%$ level * Significance at $5 \%$ level

The $Z$ values with regard to Job and Departmental Commitment of the respondents belonging to Men's Colleges and Women's Colleges are less than the table values. Hence, the hypothesis is accepted in these cases. In all other cases, it is rejected. 
It is clear from the above in the case of Lecturers belonging to men and women colleges there is no significant differences between mean scores with regard to Job and Departmental Commitment. This means that in case of teachers working in Men and Women Colleges there is no difference in the levels of job commitment and departmental commitment and these commitments are higher than their organizational commitment. The teachers of co-educational institutions have higher job commitment than departmental commitment and their departmental commitment is higher than their organizational commitment.

\section{Dimensions of Commitment and Autonomous Status}

The mean scores of opinion of the respondents belonging to autonomous and non-autonomous colleges with regard to different dimensions of commitment are given in the following table:

Table 5: Mean Scores of Job, Departmental, Organizational and Overall Commitments

\begin{tabular}{|l|c|c|c|c|}
\hline \multirow{2}{*}{ Autonomous Status } & \multicolumn{3}{|c|}{ Mean Scores of Dimensions of Commitment } \\
\cline { 2 - 5 } & Job & Departmental & Organizational & Overall \\
\hline Autonomous $(\mathrm{N}=124)$ & 4.1906 & 4.1980 & 3.8447 & 4.0650 \\
Non autonomous $(\mathrm{N}=476)$ & 4.2620 & 4.2005 & 3.8579 & 4.0981 \\
\hline Total $(\mathrm{N}=600)$ & 4.2473 & 4.2000 & 3.8852 & 4.0913 \\
\hline
\end{tabular}

It is inferred from the mean score table, that the teachers belonging to Autonomous Colleges have more or less similar scores with regard to Job and Departmental Commitment followed by Organizational Commitment. In the case of teachers belonging to Non-autonomous Colleges they have the highest mean score in respect of Job Commitment followed by Departmental and Organizational Commitment.

The significance of difference in mean scores between dimensions of commitment is illustrated in the following table : 
Table 6: Significance of difference in mean scores between dimensions of commitment Autonomous status (z-test)

\begin{tabular}{|l|r|r|r|r|r|r|r|}
\hline $\begin{array}{c}\text { Autonomous } \\
\text { Status }\end{array}$ & \multirow{2}{*}{$\mathrm{N}$} & \multicolumn{6}{|c|}{$\mathrm{Z}$ Values } \\
\cline { 3 - 8 } & & $\mathrm{J} \& \mathrm{D}$ & $\mathrm{J} \& \mathrm{O}$ & $\mathrm{J} \& \mathrm{~T}$ & $\mathrm{D} \& \mathrm{O}$ & $\mathrm{D} \& \mathrm{~T}$ & $\mathrm{O} \& \mathrm{~T}$ \\
\hline Autonomous & 124 & -0.282 & $7.317^{\star \star}$ & $6.204^{\star \star}$ & $8.138^{\star \star}$ & $7.219^{\star \star}$ & $-7.437^{\star \star}$ \\
Non-Autonomous & 476 & $3.709^{\star \star}$ & $20.948^{\star \star}$ & $16.322^{\star \star}$ & $17.201^{\star \star}$ & $9.729^{\star \star}$ & $-20.247^{\star \star}$ \\
\hline
\end{tabular}

J-Job Commitment; D-Departmental Commitment; O-Organizational Commitment; T-Total Commitment

** Significant at $1 \%$ level * Significance at $5 \%$ level

The $Z$ value with regard to Job and Departmental Commitment of the respondents belonging to Autonomous Colleges is less than the table value. Hence, the hypothesis is accepted in this case. In all other cases, it is rejected.

We may infer from the table, that there is no significant difference between mean scores of Job and Departmental Commitment of Autonomous College teachers which indicates that job and departmental commitment of Autonomous college are at the same level and these commitments are higher than their Organizational Commitment. The teachers of nonautonomous institutions have higher job commitment than departmental commitment and their departmental commitment is higher than their organizational commitment.

\section{Dimensions of Commitment and Accreditation Status}

The mean scores of opinion of the respondents belonging to accredited and non-accredited colleges with regard to different dimensions of commitment are given in the following table :

Table 7: Mean Scores of Job, Departmental, Organizational and Overall Commitments

\begin{tabular}{|l|c|c|c|c|}
\hline \multirow{2}{*}{ Accreditation Status } & \multicolumn{4}{|c|}{ Mean Scores of Dimensions of Commitment } \\
\cline { 2 - 5 } & Job & Departmental & Organizationa & Overall \\
\hline Accredited $(\mathrm{N}=244)$ & 4.2490 & 4.2078 & 3.9143 & 4.1147 \\
Non-accredited $(\mathrm{N}=356)$ & $4.246)$ & 4.1947 & 3.8147 & 4.0752 \\
\hline Total $(\mathrm{N}=600)$ & 4.2473 & 4.2000 & 3.8552 & 4.0913 \\
\hline
\end{tabular}


It is clear from the mean score table, that the teachers belonging to both Accredited and Non accredited institutions have the highest mean scores in respect of Job Commitment followed by Departmental Commitment and Organizational Commitment.

The significance of difference in mean scores between dimensions of commitment is illustrated in the following table:

Table 8: Significance of difference in mean scores between dimensions of commitment based on Accreditation status (z-test)

\begin{tabular}{|l|r|r|r|r|r|r|r|}
\hline $\begin{array}{c}\text { Accreditation } \\
\text { Status }\end{array}$ & \multirow{2}{*}{$\mathrm{N}$} & \multicolumn{6}{|c|}{$\mathrm{Z}$ Volues } \\
\cline { 3 - 8 } & & $\mathrm{J} \& \mathrm{D}$ & $\mathrm{J} \& \mathrm{O}$ & $\mathrm{J} \& \mathrm{~T}$ & $\mathrm{D} \& \mathrm{O}$ & $\mathrm{D} \& \mathrm{~T}$ & $\mathrm{O} \& \mathrm{~T}$ \\
\hline Accredited & 244 & 1.778 & $10.995^{\star \star}$ & $9.198^{\star \star}$ & $9.567^{\star \star}$ & $6.090^{\star \star}$ & $-10.481^{\star *}$ \\
Non-Accredited & 356 & $2.845^{\star \star}$ & $19.438^{\star \star}$ & $15.015^{\star \star}$ & $17.217^{\star \star}$ & $10.495^{\star \star}$ & $-19.299^{\star \star}$ \\
\hline
\end{tabular}

J-Job Commitment; D-Departmental Commitment; O-Organizational Commitment; T-Total Commitment

** Significant at $1 \%$ level * Significance at $5 \%$ level

The $Z$ value of Job and Departmental Commitment of the respondents belonging to Accredited Institutions is less than the table value. Hence, the hypothesis is accepted in this case and in all other cases the hypothesis is rejected.

From the table, it is evident that there is no significant difference between mean scores of teachers of Accredited Colleges and Non-accredited colleges with regard to Job and Departmental Commitment. This means that the job commitment and departmental commitment of teachers working in Accredited Colleges are at the same level and these commitments are higher than their organizational commitment. The teachers of non- accredited colleges have higher job commitment than departmental commitment and their departmental commitment is higher than their organizational commitment. 


\section{Dimensions of Commitment and Location of Institutions}

The mean scores of opinion of the respondents belonging to rural, semiurban and urban colleges with regard to different dimensions of commitment are given in the following table:

Table 9: Mean scores of Job, Departmental, Organizational and Overall commitments

\begin{tabular}{|l|c|c|c|c|}
\hline \multirow{2}{*}{ Location } & \multicolumn{4}{|c|}{ Mean Scores of Dimensions of Commitment } \\
\cline { 2 - 5 } & Job & Departmental & Organizational & Overall \\
\hline Rural $(\mathrm{N}=315)$ & 4.2414 & 4.2097 & 3.8714 & 4.0972 \\
Semi-Urban $(\mathrm{N}=164)$ & 4.2325 & 4.1689 & 3.8015 & 4.0589 \\
\hline Urban $(\mathrm{N}=121)$ & 4.2826 & 4.2169 & 3.8856 & 4.1197 \\
\hline Total $(\mathrm{N}=600)$ & 4.2473 & 4.2000 & 3.8552 & 4.0913 \\
\hline
\end{tabular}

It is evident from the mean score table, that the teachers working in the rural, semi-urban and urban institutions have the highest mean scores in respect of Job Commitment followed by Departmental and Organizational Commitment.

The significance of difference in mean scores between dimensions of commitment is illustrated in the following table:

Table 10: Significance of difference in mean scores between dimensions of commitment based on Location (z-test)

\begin{tabular}{|l|r|r|r|r|r|r|r|}
\hline \multirow{2}{*}{ Location } & \multirow{2}{*}{$\mathrm{N}$} & \multicolumn{5}{|c|}{ Z Values } \\
\cline { 3 - 7 } & & $\mathrm{J} \& \mathrm{D}$ & $\mathrm{J} \& \mathrm{O}$ & $\mathrm{J} \& \mathrm{~T}$ & $\mathrm{D} \& \mathrm{O}$ & $\mathrm{D} \& \mathrm{~T}$ & $\mathrm{O} \& \mathrm{~T}$ \\
\hline Rural & 315 & 1.620 & $14.487^{\star \star}$ & $11.412^{\star \star}$ & $13.172^{\star \star}$ & $8.839^{\star \star}$ & $-14.288^{\star \star}$ \\
Semi-urban & 164 & $2.282^{\star}$ & $12.181^{\star \star}$ & $10.126^{\star \star}$ & $10.137^{\star \star}$ & $6.010^{\star \star}$ & $-11.491^{\star \star}$ \\
Urban & 121 & $2.086^{\star}$ & $10.647^{\star \star}$ & $8.406^{\star \star}$ & $9.411^{\star \star}$ & $5.076^{\star \star}$ & $-10.644^{\star \star}$ \\
\hline
\end{tabular}

J-Job Commitment; D-Departmental Commitment; O-Organizational Commitment; T--Total Commitment

** Significant at $1 \%$ level * Significance at $5 \%$ level 
The $Z$ value with regard to Job and Departmental Commitment of the respondents belonging to rural institutions is less than the table value. Hence, the hypothesis is accepted in this case and in all other cases, it is rejected.

From the table, it is clear that there is no significant difference between mean scores of teachers of rural colleges with regard to Job and Department Commitment which means that the teachers working in these institutions have the same level of Job Commitment and Departmental Commitment and these commitments are higher than their organizational commitment. The teachers working in semi-urban and urban institutions have higher job commitment than departmental commitment and their departmental commitment is higher than their organizational commitment.

\section{Results and discussion}

From the above we may infer that by and large the teachers' Job Commitment is higher than their Departmental and Organizational Commitment. It is established through Differential Analysis that there is significant difference between Job and Organizational commitment.

However, in the case of Job and Departmental Commitment, there is no significant difference between mean scores with regard to teachers belonging to Govt. and Aided colleges, Men and Women's colleges, Autonomous colleges, Accredited colleges and Rural colleges. In these cases the Job Commitment and Departmental Commitment are of same level.

The reason for the teachers to be more committed towards their job than department and institution is quite understandable. In any educational institution, the core role expected of any teacher is to be a teacher focused to core work. In this study, the major components of teacher's job are Passion for teaching, Dedication to students and Innovative teaching methods. The findings prove that the teachers are very much committed to their job. The mean scores of Departmental Commitment across all the variables are very near to the scores of Job Commitment and in a few cases these are slightly better than the scores of Job Commitment. This indicates that the teachers have close attachment to the department and are much committed to it. The scores across all the variables of organizational commitment on the basis of three dimensions suggest that organizational Commitment of teachers is somehow weaker compared to job and departmental commitment 
From the above we may infer a pattern where the Job commitment and Departmental commitment always get top priority. The commitment of teachers to Organization is above average however it is less when compared with Job and Departmental Commitment.

\section{References:}

Allen, N.J. \& Meyer, J.P. (1990). The measurement and antecedents of affective, continuance and normative commitment. Journal of Occupational Psychology, 63, 1- 18.

Coladarci, T. (1992). Teachers sense of Efficacy and Commitment to Teaching. Journal of Experimental Education, 60 (4), $323-337$.

Graham, K.C. (1996) Running ahead. Enhancing Teacher Commitment. Journal of Physical Education. Recreation and Dance, 67(1), pp. 45-47.

Mueller, C.W., Wallace, J.E., \& Price, J.L (1992), Employee Commitment : Resolving some issues. Work and Occupations, 19, $211-236$.

Punia, B.K. (2000), Commitment among University Teachers : A comparative analysis, University News, Vol : 38, No. 15, April 10, pp. 7- 10.

Singh, K., \& Billingsley, B.S. (1998). Professional support and its effects on teachers' commitment, Journal of Educational Research, 91 (4), 229-239.

24th Annual Report-Year 2005, Bharathiar University, Coimbatore. 